\title{
O Mercosul na política de integração de Venezuela
}

\author{
Mercosur in Venezuela's integration policy
}

José Briceño-Ruiz*

\begin{abstract}
Resumo: Neste artigo argumenta-se que a estratégia do governo Chávez de solicitar a adesão ao Mercosul deve ser contextualizada no quadro das mudanças políticas internas na Venezuela e da forma como estas mudanças tem influído na elaboração e aplicação de política externa deste país. Neste sentido, qualquer decisão do governo venezuelano em matéria de integração regional está subordinada à consecução dos três objetivos básicos da política exterior do país: a luta contra a ordem unipolar, transformada nos anos recentes em anti-imperialismo; a rejeição ao neoliberalismo, que se converteu em anticapitalismo e a promoção da integração bolivariana. A dificuldade de compatibilizar os objetivos da política exterior venezuelana com a realidade política, estratégica e regulamento institucional do Mercosul e os custos econômicos que teria para o país adotar o programa de liberalização do Protocolo de Caracas explicam as dificuldades da adesão venezuelana ao Mercosul.
\end{abstract}

Palavras-chave: Mercosul; Venezuela; Hugo Chávez; Política externa

Abstract: In this article, we argue that the Hugo Chávez's strategy to apply for full membership into Mercosul must be contextualized in the framework of political changes in Venezuela and of the extent to which these changes have influenced the foreign policy decision making process in this country. Consequently, any decision-making on regional integration adopted in Venezuela is subordinated to the achievement of three foreign policy objectives: the fight against a unipolar order, which was recently transformed into an anti-imperialism campaign; the rejection of neo-liberalism and the capitalist system, and the promotion of Bolivarian integration. The difficulties in making these foreign policy objectives with the strategic, political and institutional reality in Mercosul compatible, and the economic costs of implementing the trade liberalization approved in the Protocol of Caracas explain why it is so hard for Venezuela to be a Mercosul full member.

Keywords: Mercosul; Venezuela; Hugo Chávez; Foreign policy

\footnotetext{
* Mestre em Relacções Internacionais pela Universidade de Durham, Inglaterra, doutorando em Ciência Política no Instituto de Estudios Políticos de Aix en Provence; é profesor e pesquisador do Centro de Estudios de Fronteras e Integración da Universidad de los Andes, Mérida, Venezuela, além de autor e compilador de vários livros sobre a integração latinoamericana.<bricenoruiz@hotmail.com>.
}

\begin{tabular}{|l|l|l|l|l|l|}
\hline Civitas & Porto Alegre & v. 10 & n. 1 & p. 77-96 & jan.-abr. 2010 \\
\hline
\end{tabular}




\section{Introdução}

Em dezembro de 1998, Chávez, que havia aparecido no cenário político venezuelano poucos anos antes como líder de um golpe de estado frustrado, obtém um triunfo retumbante nas eleições presidenciais. Este foi o início de uma nova etapa na vida política de um país que foi, durante décadas, uma das democracias mais consolidadas da região. A ascensão de Hugo Chávez ao poder produziu um estremecimento na estrutura política, com repercussões internas e externas de grande significado.

A política externa e a política de integração são duas áreas onde se podem perceber com clareza as mudanças no sistema político venezuelano. A decisão de solicitar em 2005 a adesão ao Mercosul é uma das manifestações mais claras do cambio da estratégia internacional do governo de Venezuela.

Neste artigo argumenta-se que a estratégia do governo Chávez de solicitar a adesão ao Mercosul deve ser contextualizada no quadro das mudanças políticas internas na Venezuela e a forma como estas mudanças tem influído na elaboração e aplicação de política externa deste país. Dois fatos devem ser salientados neste processo. Na esfera da política econômica, Chávez acabou o projeto de reforma econômica neoliberal aplicada em Venezuela na década dos anos noventa. No âmbito político, tem acontecido uma ruptura importante na estratégia internacional da Venezuela, particularmente nos princípios e orientações da sua política externa.

Estas mudanças explicam as respostas contraditórias nos países do Mercosul ao cenário de um Mercosul no qual a Venezuela seja um membro pleno. Em geral, pode-se argumentar que a inclusão da Venezuela tem sido, em grande parte, o resultado das mudanças no cenário político regional, que desde 2002 experimentou um giro para governos de centro-esquerda na Argentina, no Brasil e no Uruguai. Apesar das diferenças com o governo venezuelano, nestes três países se percebe que Caracas poderia ser um bom sócio, como ficou claro na $4^{\text {a }}$ Cúpula das Américas, realizada na cidade de Mar del Plata, em novembro de 2006, na qual a Venezuela apoiou o Mercosul no que diz respeito as suas criticas à Área de Livre Comércio das Américas (Alca). Isto permite argumentar que a inclusão do novo membro pleno foi uma decisão política e não foi o resultado de uma avaliação estilo União Européia do grau de preparação da Venezuela para ingressar no bloco regional.

$\mathrm{O}$ ingresso venezuelano é bem-vindo por diversos fatores. Em primeiro lugar, o Mercosul tem, a partir da incorporação venezuelana, uma maior dimensão regional sul-americana ao estender suas fronteiras até o Mar do 
Caribe. Em segundo lugar, o novo sócio é um importante produtor de petróleo e gás, o que fornece ao Mercosul uma dimensão energética que fortalece o bloco regional. Em terceiro lugar, devido à atual conjuntura dos melhores preços do petróleo, o governo venezuelano dispõe de recursos financeiros que podem ser utilizados para financiar alguns projetos regionais de infraestrutura ou mecanismos como o Fundo de Convergência do Mercosul (Focem). Finalmente, o mercado venezuelano se converte num espaço no qual os produtores mercosulianos podem ampliar e diversificar sua oferta produtiva.

No entanto, existe no Mercosul a preocupação de que o presidente venezuelano possa tentar utilizar este processo de integração como uma nova plataforma no seu confronto com os Estados Unidos. Além disso, objeta-se quanto ao discurso anticapitalista do governo venezuelano nos anos recentes e à falta de clareza da sua proposta do Socialismo do Século 21. Relacionado com este último aspecto, recusa-se as asseverações reiteradas do presidente venezuelano no que diz respeito à necessidade de "reformatar o Mercosul". Chávez opõe-se ao neoliberalismo e tem manifestado a necessidade de uma reformatação do Mercosul e a sua descontaminação do neoliberalismo. Para compreender este complexo cenário se precisa analisar as mudanças na política externa venezuelana.

\section{A política externa de Hugo Chávez}

A política externa dos governos venezuelanos entre 1950 e 1998 esteve em boa medida delimitada pela condição de país ocidental, democrático (em uma região dominada por governos de facto) e petroleiro, que começou a receber importantes recursos desde o primeiro boom do preço do petróleo da década de 1970. Estes fatores determinaram as prioridades geográficas de sua política externa, na qual os Estados Unidos apareciam como um parceiro natural na defesa da democracia e com o qual a Venezuela podia partilhar uma estratégia assistencialista na Bacia do Caribe com vistas a evitar a expansão do comunismo através de Cuba (Josko de Guerón, 1984).

O governo de Hugo Chávez produziu um desmoronamento das premissas tradicionais da política externa venezuelana, o que significou uma ruptura com alguns dos princípios tradicionais sustentados pelo Venezuela desde 1958. A nova estratégica propõe como metas: a) a promoção de um mundo multipolar; b) o fortalecimento da cooperação sul-sul; e c) a promoção do ideal bolivariano de integração. O segundo e o terceiro aspectos são reiterados na política externa venezuelana nas últimas décadas, embora Chávez lhes tenha dado uma configuração particular. 
Em diversas ocasiões e em distintos foros, Chávez manifestou a necessidade de se criar um mundo multipolar. Na ótica de Chávez, a ordem global posterior à Guerra Fria caracterizar-se-ia pelo unipolarismo norte-americano, o que significaria um desequilíbrio de poder nas relações internacionais. Por isto, seria necessário criar, segundo Chávez, pólos alternativos de poder que permitissem restabelecer o equilíbrio perdido com a conclusão da Guerra Fria. Em entrevista para a revista Foreign Affairs, o presidente venezuelano assinalou:

Hay que luchar contra un mundo unipolar y a favor de un nuevo orden internacional del que se viene hablando desde hace ya décadas, pero que se ha quedado en el discurso. Una política internacional justa, democrática, equilibrada resulta indispensable. Pero para lograrlo hay que contribuir a la creación de ese mundo pluripolar. Este es un objetivo estratégico esencial (Chávez, 2003).

Em estreita relação com o ataque ao unipolarismo, inscreve-se o segundo objetivo da política externa do governo de Chávez: a cooperação sul-sul. O governo venezuelano implementou uma ativa diplomacia para reativar os mecanismos de cooperação entre as nações em desenvolvimento, como o Grupo dos Quinze, o Grupo dos 77, o Movimento dos Não-Alinhados e o Grupo do Rio, entre outros. Venezuela foi também um dos fundadores do Grupo dos 20 (G-20), instância criada por vários países em desenvolvimento na Reunião Ministerial da OMC realizada em Cancun, em 2003.

Um elemento fundamental desta estratégia é o desenvolvimento de uma diplomacia petroleira, que teve duas vertentes. Em seus primeiros anos, sua meta fundamental foi resgatar a influência da Organização de Países Exportadores de Petróleo (Opep), na determinação dos preços do produto. Neste sentido, Chávez desenvolveu uma diplomacia pessoal que incluiu várias visitas a todos os países membros da organização e a realização no ano 2000 de uma Cúpula de Chefes de Estado da Opep em Caracas. Uma segunda vertente é a utilização dos recursos resultantes dos elevados preços do petróleo a partir de 2003 para promover a cooperação sul-sul. Assim, a Venezuela vende petróleo em condições especiais, de preços e pagamento, aos países do Caribe, América Central, Cuba, Uruguai e Argentina. Estes programas são parte de iniciativas como Petrosur, Petrocaribe e Petroamérica.

O terceiro elemento da política externa de Chávez é a promoção da integração latino-americana. Neste sentido, pretende resgatar a ideia de criação de uma comunidade latino-americana de nações, que se converta em um pólo de poder mundial. Este objetivo foi estabelecido no programa de governo 2000-2006, no qual se indica que 
el sueño bolivariano de constituir la gran Confederación de Naciones mestizas del continente aún tiene vigencia. No es utopía. Se torna más bien, una necesidad fundamental para darle solidez y consistencia a todas y cada una de las naciones de nuestro entorno político, cultural y geográfico (Ministerio de Planificación y Desarrollo, 2005).

Entre 1999 e 2001, a ideia de uma Confederação Latino-Americana foi em oposição à proposta norte-americana de criação da Alca; crítica esta que se radicaliza a partir de 2003 (Briceño Ruiz, 2006). Embora a proposta alternativa da Alba tenha sido anunciada em dezembro de 2001, nos marcos da Cúpula de Chefes de Estado e de Governo da Associação de Estados do Caribe (AEC), esta converteu-se em um elemento central da política de integração da Venezuela somente a partir de 2004, quando em função de sua vitória no referendo revogatório convocado pela oposição venezuelana, Chávez delimitou uma política exterior de notório caráter anti-imperialista e anti-norte-americano.

Este processo de definição e redefinição da estratégia internacional do governo de Hugo Chávez manifestou-se em sua política de integração regional. Nos primeiros anos, o presidente venezuelano insistia na ideia de criar uma Confederação Latino-Americana, que deveria ter um conteúdo majoritariamente político, ao mesmo tempo em que criticava a proposta de criação da Alca. Posteriormente, a partir de 2001, anunciava-se a Iniciativa Bolivariana para as Américas (Alba), embora tenha sido somente a partir de 2003 que se começou a delimitar o conteúdo da proposta, passando de uma estratégia de crítica para uma estratégia de rejeição à proposta da Alca. A partir de 2004 torna-se mais clara a estratégia de integração do governo venezuelano, que começa a refletir as ideias antineoliberais e antiestadunidense dos grupos radicais do chavismo. A ascensão de governos de esquerda no Brasil, Argentina e Uruguai e a decisão dos países andinos de negociar um tratado bilateral de livre comércio com os Estados Unidos determinaram duas decisões fundamentais que implicaram em uma mudança na estratégia de integração da Venezuela: a sua saída da Comunidade Andina (CAN) e a solicitação de entrada como membro pleno no Mercosul.

\section{A política de integração de Venezuela}

Historicamente, as iniciativas de integração regional da Venezuela foram centradas na promoção de uma liderança na Bacia do Caribe, utilizando para isto mecanismos de cooperação econômica, embora desde o final dos anos 1990 tenha sido decidido promover a integração econômica propriamente. O outro espaço natural era a região andina, aonde o país buscou manter uma liderança 
partilhada com a Colômbia e uma participação ativa no Pacto Andino. De muito menos importância foi a presença do país na fachada amazônica, que se limitou à assinatura do Tratado de Cooperação Amazônica (TCA), em 1978, mas acompanhado de escassas relações com o Brasil, o qual não poucas vezes foi considerado como um país com ambições hegemônicas na região.

A partir de 1989, a Venezuela converteu-se em um dos principais promotores de um novo regionalismo na Bacia do Caribe. Por um lado, Caracas assinou acordos bilaterais de comércio e investimentos com países como Guiana e Trinidad e Tobago. Por outro lado, decidiu promover acordos comerciais com esquemas já existentes como a Comunidade do Caribe (Caricom) e o Mercado Comum Centro-Americano (MCCA), ou foram criados novas iniciativas sub-regionais como o Grupo dos Três (G-3), do qual também participavam Colômbia e México. Finalmente, Venezuela participou ativamente no estabelecimento da Associação de Estados do Caribe (AEC), iniciativa de integração que se converteu em um marco institucional do novo regionalismo caribenho ao incluir a todos os países e territórios existentes na zona (Briceño Ruiz, 1997; Serbín, 1994).

Igualmente, a região andina e, especialmente, as relações com a Colômbia, constituíram-se no outro eixo central de suas relações exteriores. Este último país representou uma área prioritária para a política externa venezuelana, por existir uma longa história de desconfiança mútua que obedece a percepções sobre perdas de território e sobre o diferendo sobre delimitação de águas marinhas e submarinas no Golfo da Venezuela (Ramirez, Hernández, 2003).

Esta situação modifica-se ao final da década de 1980, quando os presidentes Virgilio Barco (1986-1990) e Carlos Andrés Pérez (1989-1993) relançaram o relacionamento bilateral, colocando o tema da delimitação territorial em segundo plano. Ao invés disto, optou-se por uma agenda mais centrada na cooperação e na integração, embora temas como o impacto do conflito colombiano na dimensão interna da Venezuela afetassem as relações bilaterais. Não obstante, a partir do final da década de 1980, Venezuela e Colômbia assumiram o papel de líderes no relançamento do Pacto Andino, que em 1996 foi transformado em Comunidade Andina. Caracas e Bogotá converteram-se no eixo do processo de integração andina, o que se refletiu em um incremento do comércio e dos investimentos tornando cada um deles o segundo parceiro comercial do outro (Gutiérrez, 2002).

A fachada amazônica, por outro lado, não foi uma prioridade na política exterior venezuelana; o que explica em boa medida o escasso relacionamento existente com o Brasil. Isto obedece em parte ao fato do sul venezuelano ter sido uma zona pouco povoada e não muito bem comunicada com o resto do 
território nacional até os anos 1960. Isto, de alguma maneira, afetou a relação como Brasil, que esteve basicamente centrada na delimitação territorial - que foi um processo não conflitivo, diferentemente do que aconteceu em relação à Colômbia.

Apenas ao final da década produziu-se uma primeira aproximação com o Brasil, por ser a Venezuela um dos participantes do TCA. Não obstante, o Tratado não foi bem recebido em seu momento pelo governo venezuelano que o considerava uma proposta de oposição ao Grupo Andino com vista a contrabalançar sua influência na América Latina. Outros especialistas consideraram a iniciativa "como una reacción del Brasil, ... frente ... al surgimiento de Venezuela como un nuevo poder financiero, su empeño por el liderazgo en el Tercer Mundo" (Mercado Jarrín, 1978). No entanto, houve então uma mudança de atitude da Venezuela devido à visita de Carlos Andrés Pérez a Brasília. Autores como Kucinski (1978), argumentam que nesta visita o governo brasileiro negociou o apoio à proposta venezuelana-mexicana de criar o Sela em troca do respaldo venezuelano ao TCA. A partir de então, o Tratado passou a despertar interesse se setores empresariais do Brasil e da Venezuela por acelerar as conversações e impulsionar os planos de integração regional. Pensava-se então que os projetos binacionais de infraestrutura, de exploração de recursos naturais e os programas de desenvolvimento industrial produziriam um intenso movimento de colonização em direção da Amazônia que, por sua vez, modificaria a concepção geopolítica da América Latina (Carrasco, 1978).

Entretanto, o TCA não conseguiu cumprir suas metas e apenas foi relançado ao final dos anos 1990, quando se transformou na Organização do Tratado do Atlântico Norte (OTCA). Apesar disto, o TCA converteu-se em elemento impulsionador da concertação venezuelano-brasileira em um contexto de maior cooperação e diálogo na região, embora com avanços limitados na questão de infraestrutura de estradas e proteção ambiental.

Os demais países que hoje compõem o Mercosul tiveram relações muito distantes com a Venezuela, que experimentaram momentos de apogeu, como na década de 1970 quando a Venezuela converteu-se em receptor de exilados políticos que escapavam das ditaduras da Argentina e do Uruguai; ou o apoio dado pelo governo de Luis Herrera Campins à Argentina durante a Guerra das Malvinas. Neste quadro, Venezuela esteve isolada do processo de criação do Mercosul e identificou o processo como "de los países del cono sur", sob a liderança argentino-brasileira. Neste sentido, na passagem para o anos 1990, Caracas então pretendia estabelecer um pólo no norte da América do Sul e na Bacia do Caribe através do G-3, que se converteria assim em um contrapeso do Mercosul. 
Entretanto, com a ascensão ao poder do social-cristão Rafael Caldera, em 1993, iniciou-se um processo de mudanças nas prioridades da política de integração venezuelana. O governo de Caldera deu um giro desde uma política ativa na Bacia do Caribe para a busca de uma relação mais próxima com o Brasil e o Mercosul. Desde que o primeiro mandatário venezuelano foi convidado a participar nas celebrações da independência no Brasil, em 1994, produziu-se uma aproximação bilateral, resgatando a ideia de converter o concerto venezuelano-brasileiro em um eixo da integração regional, embora esta não fosse somente um espaço amazônico mas sim sul-americana em geral. Esta aproximação consolidou-se quando Caldera convidou a seu colega brasileiro a encabeçar os atos comemorativos da independência venezuelana, em 1995.

Diversas razões explicam este novo ímpeto nas relações venezuelanobrasileiras. Em primeiro lugar, ambos países possuem uma fronteira bastante extensa, que compreende os estados brasileiros de Amazonas e Roraima, e o venezuelano de Guayana y Amazonas, entre os quais existe um relacionamento comercial muito dinâmico. Um dos eixos da nova cooperação entre Brasil e Venezuela era desenvolver políticas recíprocas e complementares. E um elemento fundamental nesta perspectiva foi o desenvolvimento da integração física, que teve início na inauguração da rodovia BR-174, que liga o território brasileiro a Caracas. Também foi iniciada a integração energética. Aproveitando que a Venezuela tem boa parte de suas represas produtoras de eletricidade no sul do país na região fronteiriça ao Brasil, combinou-se destas represas venderem energia a Roraima, ao Amazonas e ao Amapá (Villa, 2006).

Um segundo objetivo das iniciativas de integração venezuelanobrasileiras foi a promoção do intercâmbio comercial. Embora os dois países tivessem assinado um Acordo de Complementação Econômica (ACE) em 1982, foi a partir de 1993 que o comércio começou a incrementar-se alcançando 400 milhões de dólares em 1994. Esta cifra representou um incremento substancial no intercâmbio de bens e serviços. ${ }^{1} \mathrm{O}$ norte do Brasil é um mercado natural para os produtos venezuelanos. Devido a seu isolamento e distância dos centros industriais do sul brasileiro, resulta menos custosa a aquisição de bens e serviço na Venezuela, pois os custos de transporte são muito mais baixos do que implicaria levar qualquer bem desde São Paulo, Porto Alegre ou Fortaleza.

1 O intercâmbio comercial bilateral continuou crescendo desde então, para alcançar os 4.416 milhöes de dólares em 2006 (El Universal online, 7 abr. 2007). O Brasil substituiu a Colômbia como segundo parceiro comercial venezuelano em 2007. 
Esta aproximação ao Brasil significou um giro na estratégia de integração regional da Venezuela, dirigida a incorporar o país ao processo que era considerado então exitoso: o Mercosul. O interesse do governo de Caldera de entrar nesta iniciativa de integração foi manifestado desde seus primeiros meses de governo, e foi um objetivo incluído no $9^{\circ}$ Plan de la Nación, projeto quinquenal de desenvolvimento econômico do país (Economía Hoy, 5 oct, 1995). Ademais, o governo de Caldera apoiou a proposta brasileira de criar uma Área Sul-americana de Livre Comércio (a Alcsa), que seria estabelecida a partir da fusão gradual do Mercosul e da CAN. Isto também é assinalado no mencionado $9^{\circ}$ Plan de la Nación quando expressa que

el establecimiento de una zona de libre comercio en América del Sur, debe ser abordada mediante la negociación de un tratado de libre comercio con el Mercado Común del Sur, en coordinación con los demás países andinos (Economía Hoy, 5 oct. 1995).

Venezuela buscava desempenhar um papel protagônico, junto com Brasil, no estabelecimento de um bloco comercial sul-americano, com vistas a conseguir um equilíbrio frente ao Nafta. Em princípio, colocou-se a possibilidade de um acordo comercial com o Brasil; no entanto, produziu-se logo uma mudança de estratégia e se optou por solicitar a entrada no Mercosul. Esta perspectiva foi levantada inicialmente de forma unilateral, mas mais tarde foi priorizada uma negociação multilateral junto com os parceiros da CAN. O primeiro resultado destas negociações entre o Mercosul e a CAN foi a assinatura, em 1998, de um acordo marco de comércio entre ambos esquemas de integração, com o compromisso de se continuar negociando o estabelecimento de uma zona de livre comércio sul-americana para o ano 2000. Este processo negociador, não obstante, resultou ser sumamente complexo e o acordo de livre comércio não foi subscrito na data prevista, mas apenas no final de 2004. Ficou conhecido como ACE 59, e estabelece pautas para se alcançar uma zona de livre comércio entre a CAN e o Mercosul em 2018.

\section{"El giro hacia el Sur" de Hugo Chávez}

O governo de Chávez deu continuidade ao processo de aproximação ao Mercosul iniciado pelo Caldera. As relações com Brasil e a aproximação ao Mercosul constituíram objetivos-chave da estratégia de integração do governo venezuelano. Isto deveria ser entendido nos marcos de uma política externa com objetivos de construir uma ordem mundial multipolar, de fomentar a cooperação sul-sul e de promover a integração latino-americana.

Na perspectiva de Chávez, América do Sul deveria ser um dos eventuais pólos alternativos de poder para enfrentar a ordem unipolar norte-americana. A 
construção deste pólo alternativo sul-americano poderia ser realizado sobre a base da convergência entre a CAN e o Mercosul. Por isto, Chávez considerava fundamental o estabelecimento de algum tipo de aliança ou associação como Mercosul. Obviamente, para o governo venezuelano um componente desta estratégia era apresentar-se frente os países do Mercosul como um aliado contra a Alca, e ademais uma fonte de energia barata, para o qual começou a desenvolver uma ativa diplomacia petroleira com os membros do bloco a partir de 2003.

A entrada como membro pleno ao Mercosul foi um elemento importante para a política externa e de integração do governo de Hugo Chávez, tendo realizado já no ano 2000 uma solicitação formal de admissão como membro associado. Esta meta foi finalmente alcançada em 2004, quando o país foi aceito como membro associado na Cúpula realizada em junho deste ano. Entretanto, para surpresa de muitos, em outubro de 2005 Caracas anuncia sua decisão de converter-se em membro pleno. Esta solicitação foi aprovada em dezembro na Cúpula do Mercosul realizada em Montevidéu. Seis meses depois, a Venezuela e os quatro membros do Mercosul assinavam em Caracas o Protocolo de Adesão do país ao bloco. Apesar disto, o processo de adesão ainda não foi concluído devido à não-ratificação do Protocolo pelos congressos do Brasil e do Paraguai.

Durante o período de 2000 a 2003 a questão da entrada como membro associado ao Mercosul gerou discussões dentro da administração venezuelana. Segundo González Urrutia (2007), por vários anos houve um imenso debate nos níveis técnicos do Ministério de Relações Exteriores e de Produção e Comércio, instância onde havia reservas sobre a aproximação com o Mercosul. Predominava então a tese de aqueles que consideravam tal iniciativa como contrária à vocação andina mantida historicamente pelo país. Em consequência, subordinava-se esta aproximação aos benefícios alcançados na Comunidade Andina. A entrada como associado ao Mercosul "tenía que ser complementario, y no contradictorio, con el camino recorrido en el plano andino, considerado para entonces como el principal destino de nuestras exportaciones de bienes no tradicionales" (González Urrutia, 2007, p. 6). Por outro lado, neste setor se argumentava que o desenvolvimento institucional andino era muito mais avançado que o do Mercosul e, portanto, desde uma perspectiva negociadora seria muito melhor realizá-lo desde o bojo da CAN.

Por estas razões, alguns atores dentro da administração venezuelana favoreciam uma aproximação com o Mercosul "de la mano de la Comunidad Andina o mediante el fortalecimiento de ambos esquemas de integración" (González Urrutia, 2007, p. 6). Também advertiam sobre 
as possíveis contradições que geraria uma entrada plena no Mercosul devido à participação simultânea em duas uniões alfandegárias. Apesar de tudo, o governo venezuelano seguia considerando que a associação da Venezuela com o Mercosul era um objetivo estratégico da política externa do país.

Em matéria econômica, a pesar do discurso antineoliberal, existiam opiniões diversas no governo venezuelano sobre o modelo de integração. Enquanto um setor que poderíamos chamar "heterodoxo" propugnava um capitalismo intervencionista ou um socialismo mais alinhado com os partidos social-democratas europeus, setores radicais os últimos propugnavam mais bem uma estatização da economia ou uma transcendência do modelo capitalista. Durante o período de 1999-2002, o setor heterodoxo foi dominante. No Plano de Desenvolvimento Econômico e Social da Nação 2001-2007, é assinalado que se adota um modelo "vinculado con un sistema productivo diversificado, competitivo, abierto a los mercados internacionales, basado en la iniciativa privada y con presencia del Estado en las industrias estratégicas, pero con apertura a la inversión privada en el desarrollo agua abajo del tejido industrial; donde la productividad y la eficiencia deben ser la base de la rentabilidad empresarial" (Ministerio de Planificación y Desarrollo 2001, p. 13). Estes objetivos se complementariam com a promoção de uma economia social e com a promoção de políticas para cancelar a dívida social (Ministerio de Planificación y Desarrollo 2001, p. 13-14).

Este predomínio heterodoxo manifestou-se na estratégia de integração. Neste sentido, ao mesmo tempo que se ratificam objetivos de livre comércio, eram propostos o aprofundamento os acordos vigentes, colocava-se a importância de se impulsionar acordos destinados a desenvolver a agenda social e buscava-se melhorar de forma sustentada e equitativa os níveis sociais na região (Ministerio de Planificación y Desarrollo 2001, p. 156).

A polarização e radicalização do conflito político entre finais de 2001 e 2004, e a vitória final de Chávez ao sair vitorioso no referendum revogatório realizado em agosto desde último ano, produziram uma reconfiguração no interior do governo venezuelano. Como resultado deste processo, o controle político do processo foi tomado por grupos radicais.

O ano de 2004 foi um cruce de caminos na política externa de Chávez, pois este entendeu sua vitória no referendum revogatório como uma autorização para aprofundar o "processo revolucionário" em suas dimensões tanto interna quanto externa. Como assinala González Urrutia (2006), neste ano iniciou-se uma nova etapa da política exterior, manifestada na substituição do esquema tradicional de inserção internacional da Venezuela. 
Así, la consolidación del proyecto revolucionario y la conformación de alianzas geopolíticas y estratégicas con otros países pasaron a ser los ejes centrales de la política exterior. Paralelamente, se aceleró la ruptura institucional del Ministerio de Relaciones Exteriores, al tiempo que se avanzó en el proceso de ideologización de la estructura del servicio exterior (González Urrutia, 2006, p. 165).

Estes fatores incidiram sobre a estratégia de integração de Chávez, que passou a privilegiar a dimensão política com o objetivo de criar um bloco de poder que assegurasse aos países sul-americanos poder, autonomia, segurança e influência nos cenários globais. A dimensão econômica da integração passou a estar subordinada à política e era severamente criticada por se considerar uma expressão do "neoliberalismo selvagem" que havia gerado um incremento da dependência regional e não havia podido a superar a pobreza e a iniquidade na região. Como assinalam Romero e Cardoso da Silva (2002, p. 167), "esta concepción cambia completamente el terreno de discusión y de la acción, convirtiendo a la integración en un proyecto destinado a confrontar el orden mundial, sus ideas dominantes y sus estructura de poder". Desde então, a integração afastou-se da dimensão econômica e comercial e se centrou nos aspectos políticos, ideológicos e militares. Embora seja mantida uma dimensão comercial, esta é abordada desde uma ótica estatista que privilegia as relações entre empresas do estado e exclui a participação de atores não-estatais, especialmente do setor produtivo. Este seria o início da denominada integração bolivariana, que busca promover a equidade, a igualdade, a lealdade e a unidade de propósitos. Trata-se de um modelo que se propõe a transcender o econômico e comercial e que, ao invés disto, se propõe a coordenar as estratégias sociais, políticas, de segurança e as ações diplomáticas internacionais. Finalmente, esta estratégia tem um forte componente energético que se concentra na Petrosur e na proposta do Gasoduto do Sul (Jácome, 2007, p. 18).

Neste contexto, a entrada ao Mercosul converteu-se em um elemento de sua estratégia de promoção de um mundo multipolar e de enfrentamento da Alca, entendida como parte da luta contra o imperialismo estadunidense. Para o governo de Chávez, seus objetivos de política externa coincidiam com alguns elementos da estratégia promovida pelo Mercosul como a rejeição da Alca ou a ideia brasileira de se construir um bloco regional sul-americano mediante a criação da Comunidade Sul-Americana de Nações (Casa).

Não existe muita informação sobre como desenvolveu-se o debate no interior do governo venezuelano sobre a entrada como membro pleno do Mercosul. Não obstante, dois elementos são marcantes. O primeiro deles é a influência dos radicais, que concebiam o Mercosul como elemento central em 
sua ideia de construir uma ordem "multipolar". Neste enfoque, o Mercosul deveria ser entendido também como um fator na luta contra o neoliberalismo. Por isto, em reiteradas ocasiões o presidente venezuelano propôs a necessidade de reformatar o Mercosul e convertê-lo em um mecanismo a serviço dos povos. Esta percepção foi reconhecida no Proyecto Nacional Simón Bolívar, Primer Plan Socialista de Desarrollo Económico y Social de la Nación 2007-2013, no qual se propõe como objetivo "participar en la construcción del nuevo Mercosur hacia la conformación de la Comunidad Sudamericana de Naciones, sobre la base de la evaluación, revisión y reorientación de los contenidos de integración" (Proyecto Nacional Simón Bolívar 2007, p. 42). O outro elemento marcante é a crescente marca presidencial no desenho da política de integração.

Neste contexto, o Mercosul converteu-se em uma área de interesse geoestratégico. Não obstante, já nesta etapa do desenvolvimento do processo político na Venezuela, havia-se optado por uma política externa agressiva frente aos Estados Unidos e um afastamento cada vez maior dos países andinos, notório inclusive antes do anúncio formal de saída da Venezuela da CAN, em abril de 2006. O avanço das negociações do Tratado de Livre Comércio entre os Estados Unidos e os países andinos isolou a Venezuela no contexto da CAN, ademais de estar em contradição com objetivos expressos da política exterior do país como a luta contra a ordem unipolar, a cooperação sul-sul e a integração latino-americana. Foi então quando, sob o slogan "nuestro norte es el sur", o governo venezuelano decidiu buscar uma aliança maior com o Mercosul e, em 2005, solicitou a entrada como membro pleno. Foi uma notícia que surpreendeu a políticos, atores econômicos e sociais e, inclusive, acadêmicos pois, apenas um ano antes, havia sido admitido como membro associado do bloco.

\section{Além da retórica: a realidade da adesão ao Mercosul}

O objetivo de promover uma ordem mundial multipolar e estabelecer um bloco regional sul-americano coincide em alguns aspectos com a estratégia de Brasil e o Mercosul. Este bloco regional se opôs ao projeto estadunidense da Alca e a sua mais recente versão na forma de Tratados de Livre Comércio (TLC) bilaterais. A Venezuela é um novo aliado do Mercosul na sua oposição a estes projetos, como ficou claro na $4^{\text {a }}$ Cúpula das Américas, de Mar del Plata, na qual Venezuela e o Mercosul rejeitaram a iniciativa estadunidense. Caracas, por sua vez, esperava conseguir aliados com vistas a criar um bloco de poder sulamericano. Pode-se argumentar que este foi um incentivo do governo venezuelano para converter-se em membro pleno do Mercosul (Briceño Ruiz, 2009a). 
O problema é que mesmo que haja diferenças entre alguns países do Mercosul e os Estados Unidos em temas específicos de sua agenda externa, como a Alca, também existem convergências, como o interesse brasileiroestadunidense de produzir o etanol. O cenário de um Mercosul apoiando o discurso anti-Estados Unidos de Chávez não é muito realista. Este discurso inclusive tem gerado reações negativas no Brasil, o líder do Mercosul. O assessor do presidente Lula para assuntos internacionais, Marco Aurélio Garcia, numa entrevista à Folha de São Paulo criticou o discurso anti-estadunidense do presidente venezuelano. Garcia expressou que "Brasil teme uma guerra fria na região (...) Não queremos na América Latina um clima de guerra fria (...) A guerra fria já acabou. (...) a política exterior de Brasil para América do Sul e para o resto do mundo não está movida pelo prefixo anti. Nós não somos anti ninguém. Somos pró" (Folha São Paulo, 7 maio 2006). Esta opinião de um representante qualificado do governo brasileiro manifesta a vontade deste de recusar qualquer tentativa da administração venezuelana de utilizar ao Mercosul em sua diatriba diplomática contra Estados Unidos.

A luta contra o modelo neoliberal é outra variável importante que tem que ser analisada. Existe um debate no que diz respeito a se o Mercosul é uma modalidade de integração neoliberal. Não é possível neste ensaio participar nesse debate, mas é evidente que nos seus primeiros anos o Mercosul teve um forte viés comercial aberturista. No entanto, a partir da crise do real (1998) se tem produzido uma gradual revisão do modelo de integração do bloco regional. Este processo se tem aprofundado a partir do ano 2003, quando Néstor Kirchner e Luiz Inácio Lula da Silva convertem-se nos presidentes da Argentina e do Brasil. Inicia-se então uma tentativa de fortalecer a dimensão social e produtiva do Mercosul, superando assim a lógica que imperou nos anos da hegemonia do Consenso de Washington.

Chávez interpretou estas mudanças no Mercosul como uma oportunidade para promover sua agenda anti-neoliberal. Isto explica a radical proposta de reformatar o Mercosul, ao qual Chávez mesmo descreveu como um processo marcado pelo capitalismo e a concorrência feroz (El Universal, 30 jun. 2007). Assim, por exemplo, na Cúpula de Chefes de Estados do Mercosul, realizada em janeiro de 2007 no Rio de Janeiro, o presidente venezuelano apontou que se requer uma mudança interna na estrutura "do Mercosul, os objetivos, o acento social, o tratamento justo às desigualdades internas dos países, o incremento do comércio, o incremento do desenvolvimento integral, a unidade política" (Chávez, apud Minci, 2007).

Além disso, Chávez tem promovido a Alternativa Bolivariana para as Américas (Alba), como uma nova modalidade de integração não capitalista 
baseada na solidariedade, reciprocidade e cooperação. Porta-vozes do governo venezuelano expressaram que "a Alba começa no Mercosul". Numa entrevista concedida ao Diário O Mundo de Caracas, em dezembro de 2005, o Ministro de Estado para a Integração e o Comércio Exterior, Gustavo Márquez, foi interrogado a respeito de se Venezuela impulsionaria a Alba através do Mercosul. Sua resposta foi:

É desta maneira que vamos à negociação, com vistas a promover a nova integração, para que não fique numa integração só baseada no livre comércio, mas que incorporemos o aspecto social e a visão da complementação, solidariedade e cooperação (El Mundo, 7 dez. 2005, p. 10).

Depois, durante a cúpula de Caracas, realizada em julho de 2006, Márquez afirmou que

o processo de integração deve basear-se nos princípios da Alba: a complementação, solidariedade e cooperação, como instrumentos para enfrentar a pobreza e exclusão social (Boletín informativo Portal Alba, 5 jul. 2006).

Portanto, Venezuela pretendia entrar ao Mercosul com uma proposta concreta para transformá-lo segundo os princípios da Alba. Assim, o viés neoliberal que para o governo venezuelano teria caracterizado ao Mercosul deveria ser substituído pelos princípios de cooperação, solidariedade e complementação, com vistas a estabelecer um novo Mercosul, mais social e equitativo.

Várias reflexões podem-se realizar a respeito deste aspecto. A inclusão de uma agenda "além do comércio" é certamente necessária no Mercosul. A importância de discutir um novo modelo de integração surge do escasso efeito que tem tido o aumento no comércio intrarregional na promoção de uma transformação produtiva com equidade na região. Por isso, a ideia de uma integração solidária constitui uma contribuição interessante no debate a respeito de um modelo de integração adaptado às realidades da América do Sul. A integração regional não resolverá o problema da pobreza ou da exclusão, mas pode fazer uma contribuição muito maior que aquela que propõe o modelo neoliberal. Em consequência, a ideia de relançar um debate a respeito de um modelo de integração solidária é bem-vinda. No entanto, isto não poder levar a esquecer que a integração do Mercosul tem uma dimensão econômicocomercial que tem importância e na qual ainda existem temas pendentes, como o aperfeiçoamento da união alfandegária, a eliminação de regimes especiais e a coordenação de políticas. A promoção de um Mercosul social não tem que se opor a um Mercosul comercial. Os líderes do Mercosul podem promover uma agenda social, mas não vão eliminar sua agenda comercial. 
Existem razões para pensar que isto não foi considerado pelo governo venezuelano ao momento de solicitar seu ingresso como membro pleno. Isto se manifestava nas reiteradas afirmações de Chávez que para Venezuela "o norte é o sul", entenda-se, o Mercosul, por oposição aos Estados Unidos. Este discurso funcionou muito bem no âmbito político. Não obstante, a integração supõe a negociação concreta de aspectos comerciais como a desgravação tarifaria e a adoção da tarifa externa comum. Estes compromissos têm profundas consequências políticas e econômicas, pois supõem considerar as respostas dos setores sensíveis da estrutura econômica de um país e o impacto que a abertura terá no projeto de desenvolvimento nacional de um estado. Estas variáveis não eram parte do discurso oficial venezuelano quando se anunciou a adesão ao Mercosul. No entanto, uma vez iniciadas as negociações técnicas surgiram diferenças a respeito da redução das tarifas e a tarifa externa comum que derivaram num estancamento do processo de adesão da Venezuela ao bloco (Briceño Ruiz, 2009a)

Assim, no Protocolo de Caracas Venezuela se tem comprometido a adotar num lapso de quatro anos a Nomenclatura Comum do Mercosul (NCM) e a Tarifa Externa Comum. O Protocolo também estabeleceu um cronograma de liberalização comercial, segundo o qual a Venezuela deve ter livre comércio pleno com Argentina e Brasil num período de 4 anos, enquanto que para os dois sócios de menor tamanho, o período é de 6 anos. Em consequência, a Venezuela ingressaria de forma plena à zona de livre comércio no ano 2012. O Protocolo estabelece um Grupo de Trabalho para adotar o cronograma de adoção da tarifa externa comum e para negociar um programa de liberalização comercial com seus respectivos cronogramas. O Grupo de Trabalho deveria realizar a sua primeira reunião dentro de 30 dias a partir da data da firma do Protocolo, ou seja, até 4 de agosto de 2006, e concluir suas tarefas em prazo de 180 dias a partir desta reunião. Este primeiro prazo não foi respeitado, pois a primeira reunião do GT realizou-se o dia 5 de dezembro de 2006. A segunda reunião de GT foi realizada entre 4 e 6 outubro e a terceira reunião, prevista para o inicio de novembro, foi diferida por solicitação da Venezuela. Se se aceita a primeira reunião como referência para os 180 dias previstos no Protocolo, as tarefas do GT deveriam ter concluído em marco de 2007, mas esta agenda de negociação não foi respeitada. Em grande medida isto foi resultado de falta de resposta dos representantes venezuelanos às propostas realizadas pelos países do Mercosul nas reuniões do GT. A Venezuela deu sinais de que os prazos eram curtos e argumentou que os prazos dos trabalhos técnicos não devem ser mais importantes do que os prazos políticos (Rios e Maduro, 2007, p. 59). Contudo, o GT não acabou de estabelecer o cronograma 
de liberalização da Venezuela com Argentina e Brasil e as negociações estão interrompidas desde 2007 (Briceño Ruiz, 2009b).

Finalmente, a ideia de converter a Alba no modelo a aplicar no Mercosul tem que se enfrentar a realidades de tipo jurídico e político. Do ponto de vista jurídico, o Mercosul tem já um acervo comunitário constituído pelo Tratado de Assunção e todos os acordos e atos legislativos emanados das instâncias comunitárias. Nestas normas estão estabelecidos os objetivos do bloco, os mecanismos e os instrumentos para atingi-los. No artigo 3 do Protocolo de Adesão a Venezuela se compromete a adotar todo este acervo normativo. Certamente, Caracas pode promover aplicar políticas da Alba no Mercosul, mas isto terá que ser discutido nas instituições intergovernamentais do bloco, nas quais predomina o mecanismo de votação por consenso.

Do ponto de vista político, os efeitos políticos de uma hipotética pretensão de converter ao Alba em modelo para o Mercosul são importantes. Se os outros sócios aceitassem esta proposta estariam tacitamente aceitando uma mudança na distribuição de poder no grupo. Neste processo a liderança tem sido exercida pelo Brasil, país que tem sido bem-sucedido em aproveitar as mudanças globais e hemisféricas para promover uma convergência de seus interesses com aqueles da Argentina. E simplesmente impossível para a diplomacia brasileira aceitar a reconfiguração do modelo de integração econômica do Mercosul baseado nas propostas da Alba, uma iniciativa de um sócio que apenas recém se incorpora ao processo de integração. Fazer isso significaria ceder sua liderança no Mercosul.

\section{Conclusões}

A demanda venezuelana de adesão como membro pleno do Mercosul deve ser analisada no quadro da estratégia de política exterior deste país a partir da ascensão ao poder de Hugo Chávez. Neste sentido, qualquer decisão do governo venezuelano em matéria de integração regional está subordinada à consecução dos três objetivos básicos da política exterior do país: a luta contra a ordem unipolar, transformada nos anos recentes em anti-imperialismo; a rejeição ao neoliberalismo, que se converteu em anticapitalismo e a promoção da integração bolivariana.

Estas foram as motivações para ingressar ao Mercosul. Por um lado, no governo venezuelano se pensava que a oposição ao Alca pelo Mercosul e as difíceis relações da Argentina pós-default com Washington, convertiam a este bloco num aliado no conflito entre Venezuela e Estados Unidos. Além disso, a orientação de esquerda dos governos de Lula, Kirchner e Vásquez, fazia presumir uma maior independência do Mercosul frente aos Estados Unidos, 
algo que contrastava com aquilo que acontecia na Comunidade Andina, onde era maior a aproximação da Colômbia e do Peru com aquele país. Por outro lado, o discurso crítico às políticas neoliberais dos três novos governos, também fazia pensar a Chávez que o Mercosul seria um aliado em sua luta antineoliberal e anticapitalista. Neste quadro, o Mercosul era o espaço regional ideal para promover um tipo de integração latino-americana, bolivariana e solidária: a Alba, por oposição ao modelo da Alca impulsionada pelos Estados Unidos.

No entanto, a realidade tem sido muito mais complexa. Mesmo se existem diferenças sobre temas pontuais com Estados Unidos, as relações dos países do Mercosul com Washington são em general cordiais. Inclusive a Argentina não adotou um discurso antiestadunidense em sua política exterior, apesar de seu descontentamento pelo pouco apoio recebido dos Estados Unidos durante a crise de 2001. Os governos de Lula e Tabaré Vásquez, dois líderes com uma tradição de esquerda bem mais clara do que Néstor e Cristina Kirchner, tem tido excelentes relações com Washington. Algo similar aconteceu no plano econômico. Ainda que os novos governos do Mercosul, ao que se somaria Fernando Lugo em 2008, adotassem um discurso crítico ao modelo neoliberal da década de noventa, não se tem produzido uma ruptura radical com certas premissas básicas para manter a estabilidade macroeconômica. Estes presidentes também não adotaram um discurso anticapitalista, nem o plano nacional nem no Mercosul. Finalmente, o Mercosul tem um acervo normativo e institucional ou acquis communautaire formado durante vários lustros. A modificação deste modelo com base nas propostas do futuro novo sócio não era aceitável para os fundadores do bloco regional. Celso Amorim explicou isto deste modo: "Quem quer entrar num clube, primeiro aceita as regras existentes e depois (de ser aceito, se tem objeções) tenta mudá-las" (citado em Globo.com. 26 jun. 2007).

À dificuldade de compatibilizar os objetivos da política exterior venezuelana com a realidade política, estratégica e regulamento institucional do Mercosul, se adicionou outra realidade: os custos econômicos que teria para o país adotar o programa de liberalização do Protocolo de Caracas. Pode-se mesmo argumentar que o governo venezuelano percebeu isso ao começar as discussões no GT previsto no Protocolo de Caracas. Estas variáveis, junto ao complexo processo de ratificação do Protocolo nos Parlamentos do Brasil e Paraguai, explicam porque depois de mais de três anos da Cúpula de Caracas, Venezuela ainda não é um membro pleno do Mercosul.

Frente a esta realidade, pode-se argumentar que o governo venezuelano deixou considerar ao Mercosul como uma prioridade na sua política de integração. As referências ao ingresso a este bloco regional são cada vez 
menores no discurso de Hugo Chávez e nos documentos oficiais do país. Em vez disso, o governo venezuelano dedicada cada vez mais seus recursos econômicos e diplomáticos à Alba, um esquema em processo de formação, no qual Venezuela exerce a liderança, que não tem um acervo comunitário e que, em consequência, é bem mais compatível com os objetivos da política externa vigente na Venezuela desde 1999.

\section{Referências}

BOLETÍN Informativo. Portal Alba. Disponível em: <www.alianzabolivariana.org/>. 5 jul. 2006.

BRICEÑO RUIZ, José. Venezuela y la cuenca del Caribe en la segunda ola de la integración latinoamericana. Revista Mexicana del Caribe, Chetumal, v. 2, n. 3, p. 152-168, 1997.

. The free trade area of the Americas in the foreign policy of Hugo Chavez.

Unisa Latin American Report, v. 22, n. 1-2., p. 31-46, 2006.

. El Alba y el Mercosur en la agenda de integración de Venezuela: ¿son compatibles?. In: BRICEÑO RUIZ, José; MENDOZA, Carolina. Cambio y permanencia en la agenda de integración de América del Sur. Barquisimeto, Venezuela: Universidad Centroccidental Lisandro Alvarado, 2009a, p. 185-218.

. El ingreso de Venezuela como miembro pleno del Mercosur: las miradas de un proceso complejo. Revista Aportes para la Integración Latinoamericana, La Plata, v. 15 , n. 20 , p. 1-30. jun. 2009b.

CARRASCO, Juan Pablo. El Tratado de Cooperación Amazônica. Nueva Sociedad, Caracas, v. 37, p. 19-25, jul.-ago. 1978.

CHÁVEZ, Hugo. Globalización: la enfermedad del nuevo milenio (entrevista). Foreign Affairs, otoño-invierno 2001. Disponível em: <http://www.foreignaffairs-esp.org>. Acessada em: 20 fev. 2003.

ECONOMÍA HOY (EH), Caracas, 15 oct. 1995.

EL MUNDO, Caracas, 7 dic. 2005, p. 10

EL UNIVERSAL on line, 7 abr. 2007. Disponível em: <www.el-universal.com>. Acessada em 7 abr. 2007.

EL UNIVERSAL on line, 30 jun. 2007. Disponível em: <www.el-universal.com>. Acessada em 30 jun. 2007.

FOLHA SÃO PAULO, São Paulo, 7 maio 2006.

GLOBO.COM. Mercosul sai em busca do tempo perdido em integração e negociações com EU. 26 jun. 2007. Disponível em: <http://g1.globo.com/Noticias/Economia Negocios/0,,AA1574629-9356,00.html>. Acessada em: 23 out. 2009.

GONZÁLEZ URRUTIA, Edmundo. Las dos etapas de la política exterior de Chávez. Nueva Sociedad, Caracas, v. 205, p. 159-171. set.-out. 2006.

. La incorporación de Venezuela al Mercosur: implicaciones políticas en el plano internacional. Caracas: Ildis, 2007. 
GUTIÉRREZ, Alejandro. Globalización y regionalismo abierto: el caso de Venezuela y Colombia en la Comunidad Andina de Naciones. In: BRICEÑO RUIZ, José; BUSTAMANTE, Ana Marleny (Orgs.). La integración latinoamericana: entre el regionalismo abierto y la globalización. Mérida: Universidad de los Andes/Grupo Cefi/Consejo de Publicaciones, 2002, p. 91-124.

JÁCOME, Francine. Seguridad e integración bolivariana en el marco de la política exterior de Venezuela (1999-2006). Europa América Latina: Análisis e Informaciones, Rio de Janeiro: Konrad-Adenauer-Stiftung, n. 24, p. 13-37, maio 2007.

JOSKO DE GUERON, Eva. La política exterior: continuidad y cambió, contradicción e incoherencia. In: NAIM, Moises; PIÑANGO, Ramón (Orgs.). El caso Venezuela: una ilusión de armonía. Caracas: Ediciones Iesa, 1984, p. 350-375.

KUCINSKI, Bernado. La Amazonía y la geopolítica del Brasil. Nueva Sociedad, Caracas, v. 37, p. 26-30. jul.-ago. 1978.

MERCADO-JARRIN, Edgardo. El Pacto Amazónico: ¿Dominación o integración? Nueva Sociedad, Caracas, n. 37, p. 5-18, jul.-ago. 1978.

MINISTERIO de Comunicación e Información (Minci). Mercosur avanza hacia lo social, 18 ene. 2007, Noticias. Disponível em: <http://www.minci.gob.ve/noticiasprensa-residencial/28/11784/mercosur_avanza_hacia.html $>$. Acessada em 4 ago. 2007.

MINISTERIO de Planificación y Desarrollo. Plan de Desarrollo Económico y Social de la Nación 2001-2007 (2001), Caracas.

Programa de Gobierno de Hugo Chávez (2005). Equilibrio Internacional. Disponível em: <http://www.mpd.gov.ve/prog-gob/prog?gob2/e?internacionak.htm>. Acessada em: 17 maio 2005.

PROYECTO Nacional Simón Bolívar, Primer plan socialista de desarrollo económico y social de la nación 2007-2013 (2007). Caracas.

RAMÍREZ, Socorro; HERNÁNDEZ, Miguel Angel. Colombia y Venezuela: vecinos cercanos y distantes. In: RAMÍREZ, Socorro; CADENAS, José María (Orgs.). La vecindad colombo-venezolana: imágenes y realidades. Bogotá: Convenio André Bello/Universidad Nacional de Colômbia/Universidad Central de Venezuela, 2003, p. 159-241.

RIOS, Sandra, MADURO, Lucia. A adesão da Venezuela ao Mercosul, Cadernos Adenauer, São Paulo, v. 7, n. 1, p. 63-93, 2007.

ROMERO, María Teresa; CARDOSO da SILVA, Elsa. Aproximación a la apuesta internacional de Hugo Chávez: las concepciones de democracia e integración. Revista Venezolana de Análisis de Coyuntura, Caracas, Universidad Central de Venezuela, v. 8, n. 1, p. 153-173, 2002.

SERBIN, Andrés. Venezuela, el "Gran Viraje" y el proceso de regionalización en la Cuenca del Caribe. Cuadernos de Postgrado, Caracas, Universidad Central de Venezuela, n. 5, p. 67-91, 1994.

VILLA, Rafael Duarte. A política externa brasileira: capital social e discurso democrático na América do Sul. Revista Brasileira de Ciências Sociais, São Paulo, v. 21, n. 61, p. 63-89, jun. 2006. 